\title{
Meerdere banen: noodzaak of uitdaging?
}

\author{
Rien Huiskamp, Jos Sanders \& Seth van den Bossche
}

Het percentage werknemers met meerdere banen bedroeg in Nederland in 2007 ruim $7 \%$ van de totale werkzame beroepsbevolking en is al meer dan een decennium stijgende. Als aandachtsgroep in het flexibiliseringsdebat zou deze groep werknemers dus allerminst misstaan. Het verschijnsel 'meerdere banen' is in internationale studies al herhaaldelijk onderzocht, echter niet in Nederland. Onderzoek naar meerdere banen gebeurt doorgaans vanuit twee hypothesen: de 'meer uren/meer loon'-hypothese en de 'kwaliteit van het werk'-hypothese. In dit artikel worden deze hypothesen voor het eerst met Nederlandse data uit de Nationale Enquête Arbeidsomstandigheden 2007 (NEA) getoetst.

De 'meer uren/meer loon'-hypothese wordt in dit onderzoek deels bevestigd. Voor de 'kwaliteit van het werk'-hypothese vinden we geen steun. Meerdere banen is dus eerder noodzaak dan uitdaging. Beperkingen in de gebruikte data kunnen een oorzaak zijn van het gebrek aan empirisch bewijs voor de 'kwaliteit van werk'-hypothese.

Voor vervolgonderzoek is het van belang na te gaan of kenmerken van de tweede baan van invloed zijn op de keuze van werknemers voor meerdere banen. Ook van belang is na te gaan of een tweede baan een opstap is naar een betere baan of naar zelfstandig ondernemerschap.

\section{Inleiding}

De aandacht in het debat rond de flexibilisering van zowel arbeid als arbeidsmarkt is de laatste jaren vooral uitgegaan naar werknemers met tijdelijke, flexibele contracten en naar zelfstandigen zonder personeel (zzp'ers). Gezien de toename van het aandeel werknemers met meerdere banen, ligt het echter zeer voor de hand deze doelgroep als een derde categorie toe te voegen aan dit debat. Het aantal werknemers met meerdere banen is in Nederland in de afgelopen tien jaar fors toegenomen en in 2007 vormen zij met 7,2\% een substantieel deel van de werkzame beroepsbevolking. Het aandeel werknemers met een tweede baan ligt in 2007 in Nederland weliswaar iets lager dan in Denemarken en Zweden, maar het ligt wel beduidend hoger dan in België, Duitsland, Engeland en Frankrijk (zie tabel 1).

Een extra reden voor Nederlandse beleidsmakers en werkgevers om aandacht te besteden aan het groeiende aantal en aandeel werknemers met meerdere banen is het grote aandeel deeltijdwerkers in Nederland. Een deeltijdbaan geeft immers allerlei combinatiemogelijkheden. Daarmee lijkt Nederland te beschikken over

* $\quad$ Rien Huiskamp werkt als zelfstandig adviseur HRM en Arbeidsvoorwaarden. Jos Sanders en Seth van den Bossche zijn als onderzoekers/adviseurs verbonden aan TNO. De auteurs bedanken hun collega's Peter Smulders en Lando Koppes voor hun commentaar op een eerdere versie. Correspondentieadres: jos.sanders@tno.nl 
een vruchtbare voedingsbodem voor het verschijnsel van meerdere banen. Zo blijkt uit recente gegevens van CBS (Urlings, 2009) dat ongeveer een derde van degenen die de stap zetten van werknemer naar zelfstandig ondernemer, daarnaast een parttime baan aanhield.

Ten slotte kan het hebben van meerdere banen bijdragen aan een beter functionerende arbeidsmarkt. Denk bijvoorbeeld aan een tweede baan als opstap naar een nieuwe baan, als opstap van een tijdelijke naar een vaste baan of als start van een tweede loopbaan met het oog op langer doorwerken, bijvoorbeeld als doorwerken in een baan fysiek niet mogelijk is. Ook kan een tweede baan dienen als een opleidingsplek of een plek waar een werknemer de baantevredenheid realiseert die hij of zij in zijn eerste baan niet vond. Het werken in meerdere banen kan zo bijdragen aan het bevorderen van 'flexicurity': onzekerheid in de hoofdbaan of in de positie van de zzp'er kan worden gecompenseerd door het accepteren van een tweede baan die juist wel die zekerheid biedt.

Tabel 1 Percentage beroepsbevolking met een tweede baan (selectie van relevante EU-landen)

\begin{tabular}{llll}
\hline & $\mathbf{1 9 9 7}$ & $\mathbf{2 0 0 2}$ & $\mathbf{2 0 0 7}$ \\
\hline Nederland & 5,4 & 5,9 & 7,2 \\
België & 2,7 & 3,4 & 3,9 \\
Duitsland & 2,6 & 2,2 & 3,8 \\
Denemarken & 7,3 & 10,6 & 9,9 \\
Zweden & 7,9 & 9,6 & 8,1 \\
Engeland & 4,8 & 4,2 & 3,7 \\
Frankrijk & 3,3 & 3,4 & 3,1 \\
EU 27 & - & 3,6 & 3,9 \\
\hline
\end{tabular}

Bron: Eurostat (2009)

Het verschijnsel van meerdere banen wordt in de internationale onderzoeksliteratuur onderzocht vanuit grofweg twee hypothesen. De eerste (de 'hours constraint' of 'meer uren/meer loon'-hypothese) stelt dat het hebben van meerdere banen vooral een verschijnsel is aan de onderkant van de arbeidsmarkt en dat werknemers naast hun eerste baan een tweede baan nodig hebben om financieel rond te komen. Volgens deze hypothese hebben werknemers een tweede baan dus vooral uit noodzaak. De tweede (de 'heterogeneous jobs' of 'kwaliteit van het werk'hypothese) lokaliseert het verschijnsel 'meerdere banen' meer aan de bovenkant van de arbeidsmarkt. Deze hypothese stelt dat werknemers naast hun hoofdbaan andere interessante werkzaamheden in een andere baan verrichten om meer afwisseling en uitdaging te vinden. Soms is er zelfs sprake van een 'job portfolio', waarbij werknemers meerdere elkaar aanvullende banen tegelijkertijd hebben. Studies naar het verschijnsel van meerdere banen en toetsen op de genoemde hypothesen zijn tot op heden gedaan in de Verenigde Staten (Shisko \& Rostker, 1976; Smith Conway \& Kimmel, 1998; Kimmel \& Smith Conway, 2001; Renna \& Oaxaca, 2006), Groot-Brittannië (Boheim \& Taylor, 2004; Robinson \& Wads- 
worth, 2006; Dickey et al., 2009; Panos et al., 2009; Heineck \& Schwarze, 2004) en Duitsland (Heineck \& Schwarze, 2004). Voor zover wij hebben kunnen nagaan is deze studie de eerste studie waarbij de motieven van werknemers in Nederland om te kiezen voor meerdere banen centraal staan.

\section{Vraagstelling, hypothesen en onderzoeksmodel}

De centrale onderzoeksvragen voor deze studie luiden: wat is de bijdrage van de 'meer uren/meer loon'-benadering en wat is de bijdrage van de 'kwaliteit van het werk'-benadering voor het verklaren van het werken in meerdere banen in Nederland? Om een antwoord te formuleren op deze onderzoeksvragen toetsen we in deze studie een tweetal hypothesen, namelijk de 'meer uren/meer loon'-hypothese en de 'kwaliteit van het werk'-hypothese. We lichten beide hypothesen hieronder toe.

\section{De 'meer uren/meer loon'-hypothese}

De eerste en ook oudste benadering, de 'meer uren/meer loon'-hypothese, is internationaal bekend als de 'hours constraint'-hypothese. Het is de meest onderzochte hypothese en onderzoek ernaar gaat terug tot Shisko en Rostker (1976). Zij gingen ervan uit dat werknemers die in hun eerste baan niet het gewenste aantal uren kunnen of mogen werken, een tweede baan zullen zoeken. Een laag loon en/of gezinsinkomen in de eerste baan versterkt volgens hen deze keuze. Het aantal uren in de eerste baan is te weinig om voldoende te kunnen verdienen, er zijn geen mogelijkheden het aantal uren uit te breiden en dus opteert de werknemer voor een tweede baan. We vertalen in dit artikel de 'hours constraint'-hypothese voor het Nederlandse taalgebied als de meer uren/meer loon-hypothese. We spreken van 'meer uren/meer loon' omdat de primaire drijfveer voor een tweede baan voortkomt uit de onmogelijkheid om meer uren in de eerste baan te werken en zo meer inkomen te genereren. Het gaat de werknemer om meer uren en in het verlengde daarvan om meer loon. De motivatie om meer uren te werken is in de 'meer uren/meer loon'-hypothese een extrinsieke (Panos et al., 2009). Uit Brits, Amerikaans en Duits onderzoek blijkt dat werknemers die aangeven meer uren te willen werken in hun eerste baan een grotere kans hebben op een tweede baan (Kimmel \& Smith Conway, 2001; Boheim \& Taylor, 2004; Robinson \& Wadsworth, 2006; Panos et al., 2009). Ook is er een samenhang met het loon: hoe lager het loon in de eerste baan, hoe groter de kans op een tweede baan (Kimmel \& Smith Conway, 2001; Panos et al., 2009). Hetzelfde geldt voor het huishoudinkomen: er is een positief verband tussen een laag huishoudinkomen en het werken in een tweede baan (Boheim \& Taylor, 2004; Panos et al., 2009), met name als er sprake is van armoede (Kimmel \& Smith Conway, 2001). Heinick en Schwarze (2004) vinden bovendien een landeneffect: uit een vergelijking tussen Groot-Brittannië en Duitsland blijkt dat in Groot-Brittannië zowel het meer uren willen werken als meer loon van invloed zijn op de kans op een tweede baan. In Duitsland ligt het accent veel minder op het loon. De verklaring hiervoor zoeken Heinick en Schwarze in de verschillen tussen de arbeidsmarkten van Duitsland en 
Groot-Brittannië: een arbeidsmarkt met relatief veel bescherming versus een onbeschermde arbeidsmarkt. Voor het toetsen van de 'meer uren/meer loon'hypothese volgen we in dit artikel de aanname dat zowel de wens om meer uren te werken als de wens om meer loon te verwerven relevant zijn. We houden er wel rekening mee dat in een beschermde arbeidsmarkt zoals de Nederlandse, de resultaten anders kunnen zijn dan voor Groot-Brittannië en vergelijkbaar met Duitsland. Uit een experiment (Huiskamp et al., 2009) naar voorkeuren voor arbeidsvoorwaardenpakketten in Nederland blijkt dat werknemers een overweldigende voorkeur hebben voor pakketten met minder uren werken. Ze hebben daar zelfs een lager loon voor over. Dat roept de vraag op of in Nederland de 'meer uren/ meer loon'-variant überhaupt wel voorkomt.

Hypothese 1 luidt derhalve: Werknemers die in hun eerste baan meer uren willen werken, ontevreden zijn met hun loon en over een lager gezinsinkomen beschikken, werken vaker in meerdere banen.

\section{'Kwaliteit van het werk'-hypothese}

De tweede benadering, bekend onder de naam 'heterogeneous jobs', is vooral door Smith Conway en Kimmel (1998) en Boheim en Taylor (2004) uitgewerkt in navolging van Lilja (1991). In hun visie zijn er ook werknemers die een tweede baan hebben uit ander oogpunt dan het financiële. Zo biedt een tweede baan een werknemer de mogelijkheid om competenties uit de eerste baan breder te benutten. Als voorbeeld wordt vaak de hoogleraar genoemd die in eigen tijd als consultant optreedt. Een andere mogelijkheid is dat de tweede baan de werknemer plezier biedt dat in de eerste baan niet of onvoldoende te vinden is. Als voorbeeld wordt vaak de administratief medewerkster genoemd die in de avond in een band speelt. Zie bijvoorbeeld ook de titel van het artikel van Boheim en Taylor (2004) 'And in the evening she's a singer with the band'. Onderzoekers benadrukken de behoefte aan afwisseling of autonomie in het werk (Heineck \& Schwarze, 2004) en van plezier of tevredenheid met het werk (Kimmel \& Smith Conway, 2001; Renna \& Oaxaca, 2006).

We vertalen in dit artikel de 'heterogeneous jobs'-hypothese naar het Nederlandse taalgebied als de kwaliteit van het werk-hypothese. De motivatie om een tweede baan te nemen is in dit geval een meer intrinsiek inhoudelijke, dan een extrinsiek financiële (Panos et al., 2009): de behoefte aan meer kwaliteit in de huidige baan, onder andere geformuleerd in termen van autonomie, afwisseling of arbeidstevredenheid, doet iemand kiezen voor een tweede baan waarin hij of zij precies die elementen terugvindt. Voor Panos et al. (2009) is er sprake van 'heterogeneous jobs' als een werknemer heel andere dingen ('utilities') doet in of ontleent aan de eerste dan de tweede baan. Uit het onderzoek of het beroep in de tweede baan hetzelfde is als in de eerste baan, blijkt dat de financiële situatie van de werknemer van groot belang is. Als de werknemer om financiële motieven (uitgavenpatroon, laag salaris/huishoudinkomen) een tweede baan neemt, is dat vaak in hetzelfde beroep. Als een werknemer zich financieel zeker voelt in zijn eerste baan, dan kiest hij juist vaker voor een afwijkend beroep in een tweede baan. Geleidelijk wordt de 'heterogeneous jobs'-benadering in de literatuur echter bre- 
der ingevuld. Het kan inmiddels ook gaan om het streven naar meer voldoening in het werk of om een betere werk/privé-balans. Boheim en Taylor (2004) voeren bijvoorbeeld onzekerheid over het werk op als motief voor een tweede baan. Ook komt er in de internationale literatuur aandacht voor de rol van een tweede baan als een opstap naar een andere baan of naar zelfstandig ondernemerschap (Kimmel \& Smith Conway, 2001; Renna \& Oaxaca, 2006).

Voor het toetsen van de 'kwaliteit van het werk'-hypothese beperken we ons in deze studie tot een drietal indicatoren voor de kwaliteit van werk, namelijk zelfgerapporteerde variatie in het werk, autonomie en tevredenheid met arbeid in het algemeen en arbeidsomstandigheden in het bijzonder. Daarmee willen we primair voorkomen dat in de categorie 'heterogeneous jobs' alle motieven vallen die niet in de 'meer uren/meer loon'-hypothese passen en dat 'heterogeneous jobs' een containerbegrip wordt, zoals bijvoorbeeld in Dickey (2009), waar heterogeneous jobs zowel verschillende financiële als verschillende niet-financiële motieven voor het hebben van meerdere banen omvat.

Hypothese 2 luidt: Werknemers die in hun eerste baan minder variatie en minder autonomie hebben en minder tevreden zijn met het werk en met de arbeidsomstandigheden werken vaker in meerdere banen.

\section{Toevoegen andere variabelen}

Op basis van de literatuur voegen we in deze studie zoveel als mogelijk controlevariabelen aan het onderzoeksmodel toe. Zo komen we enerzijds beter te weten of Nederland inderdaad afwijkt van andere landen waar het gaat om de motieven van werknemers om meerdere banen te nemen. Ook slagen we er zo in om bij de schattingsresultaten uiteindelijk zo veel mogelijk effecten van verschillen in waargenomen variabelen te laten zien. Daarmee bereiken we schattingsresultaten die zo zuiver zijn als de ons beschikbare data toestaan. We nemen als controlevariabelen enkele persoonsvariabelen, huishoudvariabelen en baanvariabelen mee. Ze worden hieronder kort toegelicht.

Als persoonsvariabelen selecteren we de variabelen geslacht, opleiding en leeftijd. In de Verenigde Staten is geen samenhang aangetroffen tussen geslacht en de kans op een tweede baan (Robinson \& Wadsworth, 2006). In Duitsland en het Verenigd Koninkrijk echter wel. In Duitsland hebben mannen een grotere kans op een tweede baan (Heineck \& Schwarze, 2004). In het Verenigd Koninkrijk hebben juist vrouwen een grotere kans op een tweede baan (Boheim \& Taylor, 2004). Er is ook een samenhang met opleiding: hoe hoger de opleiding, hoe groter de kans op een tweede baan (Kimmel \& Smith Conway, 2001; Boheim \& Taylor, 2004; Amuedo-Dorantes \& Kimmel, 2007). Leeftijd heeft geen effect (Boheim \& Taylor, 2004; Amuedo-Dorantes \& Kimmel, 2007).

De huishoudvariabelen zijn de samenstelling van het huishouden en het aantal uren dat iemand besteedt aan huishoudelijke en zorgtaken. Onderzoek toont aan dat alleenstaanden een grotere kans hebben op een tweede baan (Amuedo-Dorantes \& Kimmel, 2007; Robinson \& Wadsworth, 2006; Panos et al., 2009). Het verband tussen kleine kinderen en de kans op een tweede baan is negatief (AmuedoDorantes \& Kimmel, 2007; Kimmel \& Smith Conway, 2001). We veronderstellen 
derhalve ook een effect van het aantal uren dat iemand besteedt aan huishoudelijke en zorgtaken op de kans op een tweede baan.

De baanvariabelen zijn omvang van het dienstverband, aard van het dienstverband, ervaren baanonzekerheid en overwerk. Een vast contract verkleint de kans op een tweede baan (Boheim \& Taylor, 2004; Heineck \& Schwarze, 2004; Panos et al., 2009). Een deeltijdbaan vergroot juist de kans op een tweede baan (Heineck \& Schwarze, 2004; Panos et al., 2009). Over een tweede baan als een 'verzekering' tegen onzekerheid in het werk en de kans op werkloosheid is de literatuur verdeeld. Volgens Panos et al. (2009) nemen werknemers een tweede baan als reactie op onzekerheid op de arbeidsmarkt of als reactie op een financiële schok (Panos et al., 2009) en Dickey et al. (2009) vinden een verband tussen onzekerheid opgevat als een tijdelijk contract en de kans op een tweede baan. Boheim en Taylor (2004) en Heineck en Schwarze (2004) vonden echter geen enkel verband tussen onzekerheid gemeten als ervaren baanonzekerheid en de kans op een tweede baan. Overwerk wordt zelden als variabele meegenomen in onderzoek naar de kans op een tweede baan. Dat is opmerkelijk omdat veel overwerk in de hoofdbaan een duidelijke aanslag betekent op de tijd die beschikbaar is voor een tweede baan. Heineck en Schwarze (2004) vonden dat betaald overwerk in de eerste baan de kans op een tweede baan verkleint. Betaald overwerk kan een antwoord zijn op de wens naar uitbreiding van het aantal arbeidsuren, vooral als het structureel van aard is en er sprake is van een overwerktoeslag.

Uit bovenstaande onderzoeken blijkt ten slotte de relevantie van de sector of het beroep waarin iemand werkzaam is. De kans op een tweede baan is groter in bijvoorbeeld sectoren als persoonlijke verzorging of beveiligingsdiensten en kleiner onder managers of onder operators in fabrieken (Kimmel \& Smith Conway, 2001; Robinson \& Wadsworth, 2006; Panos et al., 2009). In figuur 1 zijn alle variabelen gevat in een onderzoeksmodel.

\section{Figuur 1 Onderzoeksmodel}

\begin{tabular}{|l|l|l|}
\hline $\begin{array}{l}\text { Meer uren / meer loon } \\
\text { Meer uren in eerste baan } \\
\text { Ontevredenheid loon } \\
\text { Huishoudinkomen }\end{array}$ & \multicolumn{1}{|c|}{ Meerdere banen } \\
\hline $\begin{array}{l}\text { Kwaliteit van de arbeid } \\
\text { Autonomie }\end{array}$ & \\
$\begin{array}{l}\text { Afwisseling } \\
\text { Tevredenheid werk } \\
\text { Tevredenheid arbeidsomstandigheden }\end{array}$ & $\begin{array}{l}\text { Controlevariabelen } \\
\text { Persoon } \\
\text { Huishouden } \\
\text { Baan (eerste) }\end{array}$ \\
\hline
\end{tabular}




\section{Methode}

\section{Steekproef en gebruikte data}

Om bovenstaande onderzoeksvragen te beantwoorden zijn analyses uitgevoerd op data uit de Nationale Enquête Arbeidsomstandigheden (NEA) 2007. De NEA is een grootschalig periodiek onderzoek naar de arbeidssituatie van werknemers in Nederland. De versie 2007 is de vierde meting, na die van 2003, 2005 en 2006. De methodologie van de NEA is uitvoerig beschreven door Van den Bossche et al. (2008). De steekproef voor de NEA 2007 is getrokken uit het banenbestand van het Centraal Bureau voor de Statistiek (CBS). In 2007 werd de NEA ingevuld door 22.759 werknemers van 15 tot 65 jaar van de 70.000 werknemers die in 2007 werden uitgenodigd deel te nemen. Dat betekent een respons van 32,8\%. Een dergelijke respons is gangbaar bij dit type steekproefonderzoek. De enquête kon zowel schriftelijk als via internet worden ingevuld. Circa $80 \%$ van de respondenten verkoos de schriftelijke variant en $20 \%$ de webversie. Omdat bij de steekproeftrekking het risico op selectiviteit vanwege non-respons niet volledig valt uit te sluiten, is in de NEA weging toegepast. Deze weging vond plaats op basis van geslacht, leeftijd, herkomst, bedrijfstak, regio, stedelijkheid en opleidingsniveau. De NEA-steekproef vormt een representatieve afspiegeling van het werkzame deel van de Nederlandse beroepsbevolking, exclusief zelfstandigen. De NEA bevat een groot aantal vragen over de persoon, de arbeidssituatie en de kwaliteit van arbeid. In deze studie maken we op basis van de internationale literatuur gebruik van een selectie uit deze vragen. Voor een uitgebreide bespreking van de inhoud en de kwaliteit van de NEA verwijzen we naar Van den Bossche et al. (2008). Speciaal voor deze studie zijn de NEA-data verrijkt met inkomensgegevens (gezinsinkomen) uit het Integrale Inkomensbestand 2007 van het CBS. Voor 22.234 respondenten in de NEA slaagde deze koppeling.

De NEA bevat geen gegevens over een eventuele tweede of derde baan van werknemers. Het is met de NEA dus niet mogelijk analyses uit te voeren op kenmerken van een tweede baan, zoals het aantal uren dat iemand in een tweede baan werkt of het loon dat iemand er verdient. Ook over kenmerken van een eventuele tweede baan die werknemers zouden kunnen verleiden om die tweede of zelfs derde baan te nemen, zoals afwisseling, autonomie of gunstige arbeidsomstandigheden, bevat de NEA geen gegevens.

\section{Variabelen}

De te verklaren (afhankelijke) variabele in dit onderzoek is het al dan niet hebben van meerdere banen. Dit wordt vastgesteld met de vraag: Heeft u momenteel een betaalde baan? Zo ja, heeft u één of meerdere betaalde banen? De antwoordmogelijkheden zijn: (1) Nee, geen betaalde baan, (2) Ja, één betaalde baan; (3) Ja, meerdere betaalde banen. Personen zonder betaalde baan zijn buiten de analyses gehouden. In het geval waarin iemand aangeeft meerdere betaalde banen te hebben, worden vervolgvragen gesteld over de baan waarin de respondent de meeste uren maakt. Dat wordt gezien als hoofdbaan of eerste baan. Er wordt geen verdere informatie gevraagd over de andere betaalde banen. 
Schema 1 geeft een overzicht van de verklarende en controlevariabelen die we gebruiken om onze twee hypothesen te toetsen:

\section{Schema 1 Operationalisatie van de verklarende (onafhankelijke) variabelen}

\begin{tabular}{ll}
\hline \multicolumn{2}{c}{ Vraagstelling } \\
$\begin{array}{ll}\text { 'Meer uren/ meer } \\
\text { 'Meer uren'-wens }\end{array}$ \\
& $\begin{array}{l}\text { I) Wat is de omvang van uw dienstver- } \\
\text { band? } \\
\text { 2) Hoeveel uur per week zou u willen wer- } \\
\text { ken? } \\
\text { Als 2) > I) dan wil iemand meer uren wer- } \\
\text { ken. }\end{array}$ \\
$\begin{array}{l}\text { Tevredenheid met } \\
\text { het loon }\end{array}$ & $\begin{array}{l}\text { Kunt u met een rapportcijfer aangeven hoe } \\
\text { tevreden u bent over uw salaris? }\end{array}$ \\
Gezinsinkomen & $\begin{array}{l}\text { Besteedbaar inkomen van het huishouden } \\
\text { (bruto inkomen minus betaalde inkomens- } \\
\text { overdrachten, premies inkomens- en ziek- } \\
\text { tekostenverzekering en belasting op inko- } \\
\text { men en vermogen, gecorrigeerd voor ver- } \\
\text { schillen in grootte en samenstelling van het } \\
\text { huishouden). }\end{array}$
\end{tabular}

Antwoorden

'Kwaliteit van het werk'-hypothese

Autonomie in het werk*

Bepaald met een 5 item- autonomieschaal:

I) Kunt u zelf beslissen hoe u uw werk uitvoert?

$\mathrm{Ja} /$ Nee

2) Hoeveel uur per week zou u willen wer-

Als 2) > I) dan wil iemand meer uren wer-

I = zeer ontevreden

$0=$ zeer tevreden

Omgecodeerd

euro per jaar

2) Bepaalt u zelf de volgorde van uw werkzaamheden?

3) Kunt u zelf uw werktempo regelen?

4) Moet $u$ in uw werk zelf oplossingen bedenken om bepaalde dingen te doen?

5) Kunt u verlof opnemen wanneer $u$ dat wilt?

Cronbach's $\alpha=.74$

Werkvariatie* Bepaald met een 3 item- werkvariatie-

Nooit, Soms, Vaak, Altijd schaal:
I) Is uw werk gevarieerd?
2) Vereist uw baan dat u nieuwe dingen leert?
3) Vereist uw baan creativiteit?
Cronbach's $\alpha=.75$

Ja, regelmatig

Ja, soms

Nooit

Nooit, Soms, Vaak, Altijd

Tevredenheid met In hoeverre bent $\mathrm{u}$, alles bij elkaar genohet werk men, tevreden met uw werk?
I = zeer ontevreden
$5=$ zeer tevreden
Omgecodeerd
$\mathrm{I}=$ zeer ontevreden

Tevredenheid met In hoeverre bent $\mathrm{u}$, alles bij elkaar genode arbeidsomstan- men, tevreden met uw arbeidsomstandigdigheden heden? 


\section{Schema 1 (Vervolg)}

\begin{tabular}{lll}
\hline & Vraagstelling & Antwoorden \\
\hline $\begin{array}{l}\text { Controlevariabelen } \\
\text { persoon }\end{array}$ & & \\
Leeftijd & Wat is uw geboortejaar? & \\
Geslacht & Wat is uw geslacht? & Man/Vrouw \\
Opleidingsniveau & Wat is de hoogste opleiding die u heeft & Laag: geen, basisonderwijs, mavo, \\
& afgemaakt? & $\begin{array}{l}\text { V(m)bo } \\
\text { Midden: havo/vwo, mbo }\end{array}$ \\
& & Hoog: hbo, wo
\end{tabular}

Controlevariabelen

huishouden

Samenstelling huis- Hoe is uw huishouden samengesteld? houden

Gehuwd of samenwonend zonder thuiswonende kinderen

Gehuwd of samenwonend met thuiswonende kinderen Eénouderhuishouden Alleenstaand Anders

Uren besteed aan Hoeveel uur per dag besteedt $u$ gemiddeld huishoudelijke aan huishoudelijke taken en zorgtaken? uur per dag taken en zorgtaken

Controlevariabelen baan

Aard van het

Wat is de aard van uw dienstverband?

Vast: dienstverband

Werknemer met vast dienstverband (voor onbepaalde tijd)

Niet vast:

Werknemer met tijdelijk dienstverband met uitzicht op een vaste aanstelling Werknemer met tijdelijk dienstverband voor bepaalde tijd Uitzendkracht Oproepkracht/invalkracht Werkzaam via Wet Sociale Werkvoorziening (bijv. in sociale werkplaats)

Omvang van het Wat is de omvang van uw dienstverband? dienstverband uren per week (volgens contract)

Overuren (betaald Werkt u over, dat wil zeggen, meer uren of onbetaald) dan contractueel is vastgelegd?

Ja, structureel

Ja, incidenteel

Nee, nooit

Omgecodeerd 
Schema 1 (Vervolg)

\begin{tabular}{lll}
\hline & Vraagstelling & Antwoorden \\
\hline Baanonzekerheid* & Bepaald met een 2 item-werkzekerheids- & Ja, Nee \\
& schaal: & \\
I) Loopt u het risico om uw baan te verlie- & \\
zen? & 2) Maakt u zich zorgen over het behoud & \\
& van uw baan? & \\
Zelfrapportage voor werknemers die & Landbouw \\
& recent van werkgever zijn gewisseld. Aan- & Industrie \\
& gevuld met registratiegegevens CBS & Bouw \\
& & Handel \\
& & Horeca \\
& & Vervoer en communicatie \\
& Financiële dienstverlening \\
& Zakelijke dienstverlening \\
& Openbaar bestuur \\
& Onderwijs \\
& Zorg \\
& & Cultuur en overig \\
\hline
\end{tabular}

* Voor de herkomst en de psychometrische eigenschappen van de bovenvermelde schalen (onder andere Cronbach's alfa's) wordt verwezen naar Van den Bossche et al. (2008).

\section{Analyses}

De hypothesen in dit onderzoek zijn allereerst getoetst met logistische regressieanalyses. In eerste instantie is gekeken naar de bivariate effecten van de verklarende variabelen op de te verklaren variabele (meerdere banen). Daartoe zijn zeven afzonderlijke logistische regressiemodellen geschat met het al dan niet hebben van meerdere banen als afhankelijke variabele en achtereenvolgens meer uren wens, tevredenheid met het loon, gezinsinkomen, autonomie, werkvariatie, ontevredenheid met het werk en ontevredenheid met de arbeidsomstandigheden als verklarende variabelen.

Door middel van multivariate regressieanalyses zijn we vervolgens nagegaan of de bivariate effecten tussen de verklarende variabelen en het al dan niet hebben van meerdere banen (mede) worden veroorzaakt door andere factoren, die zowel met het hebben van meerdere banen als met één of meerdere van de verklarende variabelen samenhangen. Die andere factoren kunnen andere verklarende variabelen zijn. Het kunnen ook de controlevariabelen zijn, zoals genoemd in schema 1 .

Voor de multivariate regressieanalyses schatten we een tweetal logistische regressiemodellen. Om de 'meer uren/meer loon'-hypothese te toetsen schatten we een model met de drie verklarende variabelen 'meer uren'-wens, ontevredenheid met het loon en gezinsinkomen. We controleren voor alle controlevariabelen zoals genoemd in schema 1 . Om de 'kwaliteit van het werk'-hypothese te toetsen schatten we een model met de vier verklarende variabelen autonomie, werkvariatie, ontevredenheid met het werk en ontevredenheid met de arbeidsomstandigheden. Ook in dit model controleren we voor alle controlevariabelen uit schema 1. 


\section{Resultaten}

Van alle werknemers in Nederland heeft in 2007 5\% meerdere betaalde banen. Dat is minder dan de 7,2\% die Eurostat (2009) rapporteert over 2007. Voor het verschil tussen de resultaten in de NEA en de resultaten van Eurostat zijn twee verklaringen. De eerste is dat de onderzoekspopulatie voor de NEA wordt gevormd door werknemers. Personen die het merendeel van het eigen loon verdienen uit een eigen onderneming vallen buiten deze populatie en dus ook buiten de bruto steekproef voor het onderzoek. De Eurostat-gegevens worden daarentegen berekend als percentage van de gehele beroepsbevolking inclusief de zelfstandig ondernemers die nog een tweede baan in loonafhankelijke dienst kunnen hebben. Daardoor valt het percentage respondenten met een tweede baan mogelijk wat hoger uit. Een andere verklaring kan zijn dat Eurostat alléén werknemers meetelt met een baan voor 12 uur per week of meer. In de NEA zitten ook werknemers met als hoofdbaan een kleine deeltijdbaan voor minder dan 12 uur per week. De kans dat werknemers met een hoofdbaan van minder dan 12 uur per week daarnaast een tweede baan hebben voor nog minder uren per week is gering. Daardoor zal het aandeel werknemers met meerdere banen in de NEA lager liggen dan het aandeel werknemers met meerdere banen in de Eurostatgegevens.

\section{Toetsing 'meer uren/meer loon'-hypothese}

Het percentage werknemers met meerdere banen ligt hoger onder werknemers die in de eerste baan meer uren willen werken (10,7\%), onder jongere werknemers $(10,8 \%)$ en onder werknemers op tijdelijke en oproepcontracten ( $10 \%$ en hoger). Ook in de sectoren horeca, cultuur en overige dienstverlening, gezondheids- en welzijnszorg en onderwijs ligt het aandeel hoger (variërend van $9 \%$ tot $7,3 \%$ ). Werknemers met meerdere banen werken in hun eerste baan gemiddeld ruim 5 uren minder dan werknemers met één betaalde baan. Tabel 2 toont de resultaten van de logistische regressieanalyses waarin we de 'meer uren/meer loon'-hypothese toetsen.

Eerst toetsen we de drie voorspellers elk apart (bivariaat). Vooral meer uren willen werken en ontevredenheid met het loon dragen significant bij aan het hebben van meerdere banen. De hoogte van het gezinsinkomen daarentegen hangt niet samen met de kans op meerdere banen. Daarna zijn de voorspellers gezamenlijk getoetst inclusief de controlevariabelen (multivariaat). Opvallend is dat alle drie de voorspellers nu significant samenhangen met het hebben van meerdere banen. Iemand die meer uren wil werken in de eerste baan heeft een 1,7 keer zo grote kans om in meerdere betaalde banen te werken. Zowel ontevredenheid met het loon als gezinsinkomen zijn als voorspeller belangrijker geworden. Hypothese 1 , de 'meer uren/meer loon'-hypothese, is daarmee voor Nederland grotendeels bevestigd. Kanttekening is dat het gezinsinkomen de afzonderlijke toets (bivariaat) niet doorstaat en dat bij de multivariate toets de kans op meerdere banen toeneemt met de hoogte van het gezinsinkomen en niet, zoals verwacht, afneemt. 
Tabel 2 Analyse factoren 'meer uren/meer loon' Odds ratio's (Exp(B))

\begin{tabular}{|c|c|c|}
\hline & $\begin{array}{l}\text { Bivariaat } \\
\text { Odds ratio }\end{array}$ & $\begin{array}{l}\text { Multivariaat } \\
\text { Odds ratio }\end{array}$ \\
\hline Meer uren willen werken & $2,835^{* *}$ & $\mathrm{I}, 7 \mathrm{II}$ *** \\
\hline Gezinsinkomen (/12.000) & $|, 04|$ & $1,097 * *$ \\
\hline Ontevredenheid met het loon & $1,044^{*}$ & $\mathrm{I}, 052^{*}$ \\
\hline Man & . & $0,794 *$ \\
\hline Opleidingsniveau & . & $1,132 *$ \\
\hline Leeftijd & . & $0,983 * *$ \\
\hline Gehuwd zonder kinderen & . & $0,796 *$ \\
\hline Gehuwd met kinderen & . & 0,916 \\
\hline Eénoudergezin & . & 1,110 \\
\hline Alleenstaand & . & I,091 \\
\hline Anders & . & 1,132 \\
\hline Huishoudelijke en zorgtaken (uren) & . & $0,935 * *$ \\
\hline Omvang dienstverband (uren) & . & $0,966 * *$ \\
\hline Geen vast dienstverband & . & $1,396 *$ \\
\hline Overwerk & . & 0,983 \\
\hline Onzeker over behoud van baan & . & 1,094 \\
\hline Landbouw & . & 1,173 \\
\hline Industrie & . & $0,711 *$ \\
\hline Bouw & . & 0,794 \\
\hline Handel & . & $0,789 *$ \\
\hline Horeca & . & $\mathrm{I}, \mathrm{I} 58$ \\
\hline Vervoer en communicatie & . & 0,731 \\
\hline Financiële dienstverlening & . & $0,389 *$ \\
\hline Zakelijke dienstverlening & . & 1,158 \\
\hline Openbaar bestuur & . & 1,036 \\
\hline Onderwijs & . & $\mathrm{I}, 839 * *$ \\
\hline Zorg & . & $\mathrm{I}, 643 * *$ \\
\hline Cultuur en overige & . & $1,608 *$ \\
\hline $\mathrm{N}$ (aantal waarnemingen) & & 19.544 \\
\hline Nagelkerke R2 & & .082 \\
\hline Chikwadraat & & $530,490 * *$ \\
\hline $\mathrm{df}$ & & 26 \\
\hline
\end{tabular}

$*(p<.05), * *(p<.00 I)$

Het positieve verband tussen een laag gezinsinkomen en het werken in een tweede baan dat Boheim en Taylor (2004) en Panos et al. (2009) rapporteren vinden we dus niet voor de Nederlandse situatie. 
Bij de controlevariabelen zien we allereerst dat mannen in Nederland een kleinere kans hebben op meerdere banen dan vrouwen. Dat correspondeert met de bevindingen uit onderzoek in het Verenigd Koninkrijk (Boheim \& Taylor, 2004), maar druist juist in tegen resultaten van vergelijkbaar onderzoek in Duitsland, waar mannen juist een grotere kans hebben op een tweede baan (Heineck \& Schwarze, 2004). Opleiding vergroot ook in dit onderzoek de kans op een tweede baan. Daarmee worden resultaten uit onderzoek van Kimmel en Smith Conway (2001), Boheim en Taylor (2004) en Amuedo-Dorantes en Kimmel (2007) bevestigd. Leeftijd hangt in dit onderzoek negatief samen met de kans op meerdere banen. Met het toenemen van de leeftijd, neemt de kans op meerdere banen af. In eerdere onderzoeken van Boheim en Taylor (2004) en Amuedo-Dorantes en Kimmel (2007) werd een effect van leeftijd niet gevonden.

Wat betreft de huishoudvariabelen zien we dat gehuwde werknemers zonder kinderen in Nederland een kleinere kans hebben op meerdere banen dan andere werknemers. Alleenstaanden hebben niet significant meer kans op meerdere banen dan andere werknemers. Dat laatste resultaat wijkt af van resultaten in eerder onderzoek van Amuedo-Dorantes en Kimmel (2007), Robinson en Wadworth (2006) en Panos et al. (2009). De tijd die een werknemer besteedt aan zorgtaken hangt, zoals verwacht, negatief samen met de kans op meerdere banen.

Bij de baanvariabelen zien we allereerst dat werknemers met een tijdelijk dienstverband een grotere kans hebben op het hebben van meerdere banen. Dat resultaat bevestigt onderzoek van Boheim en Taylor (2004), Heineck en Schwarze (2004) en Panos et al. (2009). Ook zien we dat een groter contract (meer uren) de kans op meerdere banen verkleint, zoals ook Heineck en Schwarze (2004) en Panos et al. (2009) al vonden. Ervaren baanonzekerheid heeft geen invloed op de kans op meerdere banen. Dat bevestigt eerder onderzoek van Boheim en Taylor (2004) en Heineck en Schwarze (2004), die ook geen verband vonden. De stelling van Panos et al. (2009) dat werknemers als reactie op onzekerheid op de arbeidsmarkt een tweede baan nemen, wordt in dit onderzoek dus niet bevestigd. Het negatieve effect van overwerk op de kans op meerdere banen, dat Heineck en Schwarze (2004) in Duitsland voor betaald overwerk aantoonden, wordt in dit onderzoek niet bevestigd. Ten slotte is gekeken naar de samenhang tussen de sector waarin werknemers werkzaam zijn en hun kans op meerdere banen. Werknemers in zorg, onderwijs en cultuur en overige diensten hebben een relatief grote kans op meerdere banen. Werknemers in de industrie, handel en de financiele dienstverlening hebben juist minder kans. Deze resultaten ondersteunen de resultaten van onderzoek van Kimmel en Smith Conway (2001), Robinson en Wadsworth (2006) en Panos et al. (2009), die aantonen dat de kans op meerdere banen kleiner is onder operators in fabrieken (industrie) en groter bij beveiligingsdiensten en persoonlijke verzorging (cultuur en overige diensten).

\section{Toetsing 'kwaliteit van de arbeid'-hypothese}

Tabel 3 toont de resultaten van de logistische regressieanalyse waarin we de 'kwaliteit van het werk'-hypothese toetsen. Verklarende variabelen zijn de mate waarin iemand in de eerste baan gevarieerd werk en/of autonomie ervaart, de mate waarin iemand ontevreden is met het werk en de mate waarin iemand onte- 
vreden is met de arbeidsomstandigheden. In de bivariate toetsing is alleen autonomie in het werk een significante voorspeller voor het hebben van meerdere banen. Het effect van autonomie blijkt in de multivariate analyse echter niet meer significant. Geen van de verklarende factoren is daarmee significant. Hypothese 2, de 'kwaliteit van het werk'-hypothese, is daarmee verworpen. De gevonden samenhangen tussen de controlevariabelen en de kans op het hebben van meerdere banen wijken niet af van de samenhangen die we vonden bij de toetsing van de 'meer uren/meer loon'-hypothese.

\section{Conclusie en discussie}

Dit onderzoek bevestigt ten dele de resultaten van internationaal onderzoek onder de vlag van de 'hours constraint'-benadering, vertaald in het Nederlands als de 'meer uren/meer loon'-benadering. Het internationale onderzoek laat zien dat als werknemers in hun eerste baan niet het aantal gewenste uren kunnen of mogen werken, zij een grotere kans hebben op een tweede baan. Een laag gezinsinkomen vergroot deze kans. In dit artikel laten we zien dat werknemers in Nederland die in hun eerste baan meer uren willen werken, inderdaad vaker in meerdere banen werken. Ontevredenheid met het loon en een hoog gezinsinkomen versterken de samenhang met de keuze voor meerdere banen, zij het in beperkte mate. In combinatie met elkaar beïnvloeden ontevredenheid met het loon, gezinsinkomen en meer uren willen werken wel de kans op meerdere banen. Dit resultaat spoort met de uitkomsten van vergelijkend onderzoek tussen GrootBrittannië en Duitsland (Heineck \& Schwarze, 2004), zij het dat gezinsinkomen in Nederland een significante positieve samenhang heeft met de kans op meerdere banen, terwijl vanuit de literatuur een negatieve samenhang verwacht werd. Dit laatste kan waarschijnlijk worden verklaard doordat we gebruikmaken van cross-sectionele data, niet van longitudinale. Werknemers met meerdere banen wordt gevraagd naar het gezinsinkomen op dat moment en niet op het moment waarop zij de keuze maakten om er een baan bij te nemen. Met longitudinale data zou kunnen worden vastgesteld of een laag gezinsinkomen aan het hebben van meerdere banen in de tijd voorafgaat.

Een internationale vergelijking laat zien dat in Groot-Brittannië zowel het motief van meer uren willen werken als het laag loon/gezinsinkomen van belang is. In Duitsland is vooral het eerste motief, meer uren willen werken, van belang. De onderzoekers wijten dat aan verschillen in het functioneren van de arbeidsmarkt tussen beide landen. Duitsland kent een meer beschermde arbeidsmarkt dan Groot-Brittannië. Er gelden bijvoorbeeld veel strengere wettelijke (en cao-)bepalingen voor het aantal te werken uren. Een Duitse werknemer die meer uren wil werken, zal eerder en vaker tegen die grens oplopen dan zijn Britse collega en dus is de kans groter dat hij meer uren wil werken zonder dat de hoogte van het loon of het gezinsinkomen een belangrijke drijfveer is. Daarnaast blijkt dat een aanzienlijk aantal werknemers in Duitsland minder uren wil werken, maar dat niet mag. Er is dus een 'hours constraint' de andere kant op. In Nederland 'deeltijd- 
Tabel 3 Analyse factoren 'kwaliteit van het werk' Odds ratio's (Exp(B))

\begin{tabular}{|c|c|c|}
\hline & $\begin{array}{l}\text { Bivariaat } \\
\text { Odds ratio }\end{array}$ & $\begin{array}{l}\text { Multivariaat } \\
\text { Odds ratio }\end{array}$ \\
\hline Gevarieerd werk & 0,935 & 0,983 \\
\hline Autonomie & $0,840^{*}$ & $|| 3 \mid$, \\
\hline Ontevredenheid met het werk & 0,966 & 0,941 \\
\hline Ontevredenheid met de arbeidsomstandigheden & 0,998 & 1,040 \\
\hline Man & . & $0,806^{*}$ \\
\hline Opleidingsniveau & . & $1,124 *$ \\
\hline Leeftijd & . & $0,985 * *$ \\
\hline Gehuwd zonder kinderen & . & $0,736 * *$ \\
\hline Gehuwd met kinderen & . & $0,878^{*}$ \\
\hline Eénoudergezin & . & 1,212 \\
\hline Alleenstaand & . & 1,060 \\
\hline Anders & . & 1,162 \\
\hline Huishoudelijke en zorgtaken (uren) & . & $0,93 \mid * *$ \\
\hline Omvang dienstverband (uren) & . & $0,959 * *$ \\
\hline Geen vast dienstverband & . & $\mathrm{I}, 415^{*}$ \\
\hline Overwerk & . & 1,018 \\
\hline Onzeker over behoud van baan & . & 1,126 \\
\hline Landbouw & . & $\mathrm{I}, 200$ \\
\hline Industrie & . & $0,668^{*}$ \\
\hline Bouw & . & 0,75 I \\
\hline Handel & . & 0,832 \\
\hline Horeca & . & $|, 22|$ \\
\hline Vervoer en communicatie & . & 0,732 \\
\hline Financiële dienstverlening & . & 0,400 \\
\hline Zakelijke dienstverlening & . & 1,100 \\
\hline Openbaar bestuur & . & 0,966 \\
\hline Onderwijs & . & $\mathrm{I}, 858 * *$ \\
\hline Zorg & . & $1,636 * *$ \\
\hline Cultuur en overige & . & $1,724 * *$ \\
\hline N (aantal waarnemingen) & & 20.058 \\
\hline Nagelkerke R2 & & .074 \\
\hline Chikwadraat & & $489,512 * *$ \\
\hline $\mathrm{df}$ & & 27 \\
\hline
\end{tabular}

$*(\mathrm{p}<.05), * *(\mathrm{p}<.00 \mathrm{I})$, het contrast is telkens het gemiddelde over de totale groep

land' is de variant 'minder uren/minder loon' ook populair, zo blijkt uit een onderzoek naar voorkeuren voor arbeidsvoorwaardenpakketten. Werknemers 
hebben een overweldigende voorkeur voor pakketten met minder uren werken en hebben daar zelfs een lager loon voor over (Huiskamp et al., 2009). Een andere belangrijke motivator voor het werken in meerdere banen is een tijdelijk contract in de eerste baan. In de onderzoeksliteratuur wordt dit wel geïnterpreteerd als een 'hedge', een strategie tegen baanonzekerheid. Werknemers, in het besef dat hun baan slechts tijdelijk is, werken in een tweede baan om de continuïteit van het inkomen te bevorderen. Daartegen pleit dat in internationaal onderzoek, en ook het onze, ervaren baanonzekerheid geen effect heeft op de kans op een tweede baan.

Ons onderzoek bevestigt niet de tweede benadering die in internationaal onderzoek onder de naam 'heterogeneous jobs' bekend is. In het Nederlands is deze benadering vertaald als de 'kwaliteit van het werk'-hypothese. In onze studie hebben werknemers die in hun eerste baan weinig afwisseling en/of autonomie ervaren en/of ontevreden zijn over hun werk en/of hun arbeidsomstandigheden, geen grotere kans om ook in een tweede baan actief te zijn. Belangrijke kanttekening bij dit resultaat is dat data over de tweede of derde baan van werknemers ontbreken. In onze analyse konden we daarom geen rekening houden met verschillen in de kenmerken van de tweede baan. In internationaal onderzoek waarin de hypothese wel werd bevestigd, werd wel gebruikgemaakt van dergelijke data. Bij beperkingen van dit onderzoek verderop in deze paragraaf komen we hier uitgebreider op terug.

\section{Beleidsvragen en vervolgonderzoek}

Een belangrijke beleidsvraag die in deze studie niet wordt beantwoord is de vraag of en in hoeverre er verschillen zijn tussen de motieven voor een tweede baan bij werknemers aan de onderkant van de arbeidsmarkt en bij werknemers aan de bovenkant van de arbeidsmarkt. Uit deze studie blijkt dat werknemers met meerdere banen vaker hoger opgeleid zijn en dat zij vaker een tijdelijk of oproepcontract hebben. Ook zijn het vaker jongeren en vrouwen die gemiddeld minder uren werken in hun hoofdbaan. De studie laat daarnaast zien dat motieven voor een tweede baan primair gezocht moeten worden in de wens om meer uren te werken, enigszins versterkt door een hoog gezinsinkomen en door onvrede met het eigen inkomen. Een tweede baan is er volgens onze studie dus vooral uit financiële noodzaak en dat lijkt vooral een motief voor werknemers aan de onderkant van de arbeidsmarkt. Aan de bovenkant van de arbeidsmarkt is de verwachting dat het werknemers bij het stapelen van meerdere banen vooral gaat om het vinden van extra uitdagingen en meer afwisseling, en veel minder om het stapelen van banen uit een financiële noodzaak. Uit recent onderzoek blijkt bijvoorbeeld dat zzp'ers vooral oudere, hoogopgeleide mannen zijn en dat zij kiezen voor zelfstandig ondernemerschap uit 'positieve' beweegredenen, zoals het streven naar autonomie (Van Gelderen \& Jansen, 2006; Dekker, 2010). Ook blijkt dat een hoger huishoudinkomen voor de zzp'er functioneert als een buffer tegen de onzekerheid die het zelfstandig ondernemerschap met zich meebrengt (Dekker, 2010). Dat alles zou erop kunnen wijzen dat ook aan de bovenkant van de arbeidsmarkt de combinatie van loondienst en zzp-schap en daarmee ook het verschijnsel meerdere banen aan populariteit wint. Voor de bovenkant van de arbeidsmarkt lijken 
echter andere motieven te gelden en gaat het om een combinatie van financiële en niet-financiële motieven vanuit enerzijds de 'meer uren/meer loon'-hypothese en anderzijds de 'kwaliteit van het werk'-hypothese. Vervolgonderzoek kan meer licht werpen op de verschillen in motieven voor een tweede baan aan de onder- of bovenkant van de arbeidsmarkt.

Een tweede relevante beleids- en onderzoeksvraag is in hoeverre werknemers een tweede baan kunnen gebruiken als een opstap naar een betere baan met meer kwaliteit (betere voorwaarden en omstandigheden), waardoor iemand meer duurzaam inzetbaar is en langer productief kan participeren in het arbeidsproces. Vervolgonderzoek in een longitudinale opzet waarbij transities van één naar meerdere banen of van meerdere banen naar één baan worden gevolgd, kunnen hier informatie over verschaffen. Van een opeenvolging van transities van één baan naar meerdere banen en van meerdere banen weer naar één baan kan bekeken worden of en in hoeverre een werknemer van een 'bad job' (wenst meer uren te werken, onvrede met het loon en een tijdelijke aanstelling) de stap zet naar een 'better job' of zelfs een 'good job' (met het gewenste aantal uren, een grotere tevredenheid met het loon en een vaste aanstelling). Op deze wijze kan worden nagegaan of een tweede baan een opstap kan zijn voor werknemers aan de onderkant van de arbeidsmarkt op weg naar een betere baan. De longitudinale opzet maakt bovendien een strengere toets van de 'meer uren/meer loon'-hypothese mogelijk.

Een derde beleidsvraag voor vervolgonderzoek is in hoeverre werknemers een tweede baan kunnen gebruiken als een opstapje naar het zelfstandig ondernemerschap. In vervolgonderzoek zou dan moeten worden vastgesteld welke werknemers in hun tweede baan zzp'er zijn. De combinatie van een baan in loondienst met een eigen onderneming maakt het mogelijk een beter beeld te schetsen van de werknemers die het echt om de 'kwaliteit van het werk' gaat, om er - zoals in de literatuur omschreven - verschillende 'utilities' uit halen. Het is mogelijk dat de 'kwaliteit van de arbeid'-hypothese wel voor hen opgaat en dat zij in vergelijking met werknemers met een tweede baan in loondienst, minder gevoelig zijn voor de motieven in de 'meer uren/meer loon'-hypothese. Met vervolgonderzoek kan ook aangesloten worden bij de belangrijke stroming in recent internationaal onderzoek die meerdere banen bestudeert als opstap naar zelfstandig ondernemerschap.

Een andere relevante beleidsvraag is de vraag in hoeverre het verschijnsel van meerdere banen bijdraagt aan het beter functioneren van de arbeidsmarkt. Dat is het geval aan de aanbodkant als een tweede baan een opstap biedt naar een betere baan of als een tweede baan een opstap biedt naar zelfstandig ondernemerschap of naar baanwisseling en aldus ruimte creëert voor nieuwe instroom. Het verschijnsel van meerdere banen kan daarnaast een bijdrage leveren aan de duurzame inzetbaarheid van (oudere) werknemers, aan langer doorwerken in beter passende banen en aan het voorkomen dat werknemers vastlopen.

Ook aan de vraagkant kan het verschijnsel van meerdere banen het functioneren van de arbeidsmarkt echter bevorderen. Zo zijn Nederlandse gemeenten al enkele jaren bezig 2.500 combinatiefuncties als 'bruggenbouwers' in te vullen (Taskforce Combinatiefuncties, 2008). Deze bruggenbouwers hebben twee functies, bijvoor- 
beeld één in een onderwijsinstelling en één bij een sportvereniging of een welzijnsinstelling. Gemeenten streven naar intersectorale combinatiefuncties, waarbij randvoorwaardelijke zaken als het 'combinatiefunctieproof' maken van de verschillende cao's aan de orde zijn geweest. Organisaties kunnen een medewerker aantrekken, die in twee banen relevante ervaring opdoet of vanuit een gezamenlijke doelstelling een medewerker twee aanstellingen aanbieden, bijvoorbeeld conform het Franse 'gedeeld werkgeverschap' (Dorenbosch \& Sanders, 2010), waarbij twee of meer werkgevers één werknemer in dienst nemen.

\section{Beperkingen van dit onderzoek}

Het gaat te ver om op basis van ons onderzoek vast te stellen dat in Nederland de kans dat werknemers tweede of meerdere banen hebben alleen samenhangt met de financiële noodzaak en niet met de uitdaging die een tweede baan met zich mee kan brengen. De reden voor deze uitkomst kan namelijk liggen in de beperkingen van dit onderzoek en de gebruikte data. De data uit de NEA zijn weliswaar uitstekend geschikt voor het toetsen van de 'meer uren/meer loon'-hypothese, maar voor toetsing van de 'kwaliteit van het werk'-hypothese zijn zij minder geschikt, omdat informatie over de tweede baan ontbreekt. De 'meer uren/meer loon'-hypothese kan grotendeels getoetst worden zonder inzicht in kenmerken van de tweede baan. Het motief om te werken in een tweede baan komt immers vooral voort uit factoren die te maken hebben met de eerste baan: meer uren willen werken en onvrede met het loon (en daarnaast huishoudinkomen). Het zou echter nog beter zijn analyses uit te voeren waarin ook kenmerken van de tweede baan worden meegewogen, zoals bijvoorbeeld het aantal uren dat iemand in deze tweede baan werkt of het loon dat iemand in die tweede baan verdient. Daardoor zou het ook mogelijk zijn om na te gaan of iemand met een tweede baan meer uren werkt maar tegen hetzelfde uurloon of dat iemand in totaal nog evenveel uren werkt, maar deels tegen een hoger uurloon. Onderzoek op longitudinale data zou wellicht een scherper licht kunnen werpen op de oorzaak-gevolgrelatie tussen de hoogte van het huishoudinkomen en de keuze om in meerdere banen te gaan werken. Een laag gezinsinkomen zou vooraf kunnen gaan aan de keuze om meerdere banen uit te oefenen en aldus een hoger huishoudinkomen te verwerven. Deze relaties zijn met de in onze studie gebruikte cross-sectionele data niet te onderzoeken.

Ernstiger is wellicht de beperking van de NEA-data voor het toetsen van de tweede hypothese, de 'kwaliteit van het werk'-hypothese. Deze hypothese stelt dat de werknemer een tweede baan neemt omdat hij verwacht in die tweede baan meer afwisseling of een grotere mate van tevredenheid te vinden dan in de eerste baan. Deze hypothese kan zonder informatie over de tweede baan, bijvoorbeeld over afwisseling, autonomie of gunstige arbeidsomstandigheden in de tweede baan, zo blijkt, niet adequaat getoetst worden. Variatie en autonomie in het huidige werk en tevredenheid met het huidige werk en de huidige arbeidsomstandigheden zouden idealiter getoetst moeten worden als kenmerken van de hoofdbaan én als kenmerken van de tweede baan.

Een laatste beperking in de gebruikte data is dat werknemers die zelfstandig ondernemerschap combineren met een baan in loondienst en die het meeste ver- 
dienen in hun betrekking als zelfstandige, niet in de NEA-data zitten. De NEA is een werknemerssurvey. We beschikken daardoor wel over gegevens van werknemers die hun hoofdbaan in loondienst combineren met een kleinere baan als zelfstandige, maar niet over gegevens van zelfstandigen die hun hoofdbaan als zelfstandige combineren met een kleinere baan in loondienst.

\section{Literatuur}

Amuedo-Dorantes, C. \& Kimmel, J. (2007). Moonlighting over the business cycle. Paper for the Society for Labor Economists meeting.

Boheim, R. \& Taylor, M.P. (2004). And in the evening she's a singer with the band-second jobs, plight or pleasure. Bonn: IZA DP 1081.

Bossche, S.N.J. van den, Koppes, L.L.J., Granzier, J.J.M., Vroome, E.M.M. de \& Smulders, P.G.W. (2008). Nationale Enquête Arbeidsomstandigheden 2007: Methodologie en globale resultaten. Hoofddorp: TNO.

Dekker, F. (2010). Opvattingen van zelfstandige ondernemers over sociale zekerheid. Tijdschrift voor Arbeidsvraagstukken, 26, 146-161.

Dickey, H., Watson, V. \& Zangelidis, A. (2009). What triggers multiple job holding? Paper University of Aberdeen.

Dorenbosch, L. \& Sanders, J. (2010). Gedeeld werkgeverschap naar Frans voorbeeld. Overwerk Tijdschrift Steunpunt WSI, 2, 44-49.

Eurostat (2009). Europe in figures. Eurostat yearbook 2009, 276.

Gelderen, M. van \& Jansen, P. (2006). Autonomy as a start-up motive. Journal of Small Business and Enterprise Development, 13, 23-32.

Heineck, G. \& Schwarze, J. (2004). Fly me to the moon: the determinants of secondary jobholding in Germany and UK. Bonn: IZA DP 1358.

Huiskamp, R., Ooms, D. \& Jong, T. de (2009). Korter werken of investeren in de levensloop. Economisch Statistische Berichten, 94, 564-567.

Kimmel, J. \& Smith Conway, K. (2001). Who moonlights and why? Industrial Relations, 40, 89-102.

Lilja, R. (1991). The problematic and unproblematic second job. Discussion Paper 107. Helsinki: Labour Institute for Economic research.

Panos, G.A., Pouliakas, K. \& Zangelidis, A. (2009). The inter-related dynamics of dual job holding, human capital and occupational choice. Bonn: IZA DP 4437.

Renna, F. \& Oaxaca, R.L. (2006). The economics of dual jobholding: a job portfolio model of labor supply. Bonn: IZA DP 1915.

Robinson, H. \& Wadsworth, J. (2006). The impact of the minimum wage on the incidence of second job holding in Britain. Bonn: IZA DP 2445.

Shisko, R. \& Rosker, B. (1976). The economics of multiple jobholding. American Economic Review, 66, 298-308.

Smith Conway, K. \& Kimmel, J. (1998). Male labor supply estimates and the decision to moonlight. Labour Economics, 5, 135-166.

Taskforce Combinatiefuncties (2008). Aan het werk met combinatiefuncties. Den Haag.

Urlings, N. (2009). Van werknemer naar ondernemer. Den Haag: CBS. 